\title{
Intergenerational Transmission of Parental Risky Health Behaviors in Chinese Children: Are There Socioeconomic Differences?
}

\author{
Zexuan Yu \\ Shandong University \\ Jiajia Li ( $\sim$ lijiajia@sdu.edu.cn ) \\ Shandong University
}

\section{Research Article}

Keywords: Intergenerational transmission, Risky health behaviors, Socioeconomic status

Posted Date: December 6th, 2021

DOI: https://doi.org/10.21203/rs.3.rs-1094085/v1

License: (c) (i) This work is licensed under a Creative Commons Attribution 4.0 International License. Read Full License 


\section{Abstract}

Background: Risky health behaviors in childhood, including smoking, drinking alcohol, and poor diet, are major sources of noncommunicable diseases in adulthood. This study was intended to examine how parents affect children's risky health behaviors, and whether intergenerational transmission differed by Socioeconomic Status (SES).

Methods: Data were extracted from the 1991-2015 China Health and Nutrition Survey (CHNS). Smoking ( $n=5946)$, alcohol drinking $(n=7821)$, and sugar-sweetened beverages (SSBs) drinking $(n=3537)$ were singled out as proxies for risky health behaviors in children. A binary choice model for panel data with random effect specification was employed to examine whether the risky health behaviors can be transmitted from parents to their children. Subsequently, we conducted a seemingly unrelated test to explore the difference in parental transmission between SES groups.

Results: We found strong intergenerational persistence of smoking, alcohol drinking, and SSBs drinking behaviors, except mothers' smoking behavior. Mothers had a greater influence on children's alcohol drinking and SSBs drinking behaviors than fathers, both in urban and rural areas, and in different SES groups. The intergenerational transmission of SSBs drinking behaviors exhibited a downward SES gradient for both urban and rural families. In urban areas, mothers' drinking behavior has a downward gradient with their education level, occupation, and income, but in rural areas, the influence of mothers' drinking behavior is in the same direction with the upward gradient of education level and occupation type. In rural areas, the influence of fathers' drinking and smoking behaviors appears to show a mainly positive gradient with SES, while some become a downward gradient among urban fathers.

Conclusions: Parents' behaviors and socioeconomic status could make sense in the initiation of their offspring's risky health behaviors. To promote healthy behaviors, policymakers can introduce health education programs for parents, especially for rural areas and low SES parents.

\section{Implications And Contribution}

We estimated how parents affect children's risky health behaviors in the hope of adding up-to-date evidence to former crosssectional studies. This paper researched from a major but rarely mentioned perspective of parental influence on children's risky health behavior, the SES differences, to shed light to preventing them from the parent level.

\section{Introduction}

Risky health behaviors such as smoking, drinking alcohol, and poor diets are major preventable causes of death [1-4]. These risky health behaviors are often initiated in childhood and tend to persist into adulthood [5-8]. Thus it is of great significance to prevent them earlier in life as precursors to disease [9]. However, the prevalence of smoking, alcohol drinking, and unhealthy diet like sugar-sweetened beverages (SSBs) drinking were substantial among children and adolescents. Approximately 43 million 13-15 years old children used tobacco [10], and about 155 million adolescents were current drinkers globally in 2018[11]. Investigations from the US and China both found that over $60 \%$ of children and adolescences consumed SSB almost daily [12, 13].

Family is a major environment for children's behavior formation. For one thing, as children's first teachers and socializing agents, parents' negative health behaviors would set a false model for their children [14]. In addition to the model effect, parental socioeconomic status (SES) variables, including educational attainment, income, and occupational status, together with the parenting styles, constitute the home environment in which children's behaviors are embedded [14-19].

However, whether SES differences exist in the intergenerational transmission of unhealthy behaviors has not been sufficiently clarified. According to Cockerham's Health lifestyle theory [20], high SES parents avoid not only the transmission of their own negative health behaviors but also their gentle parenting style helps to develop children's self-control [20]. In contrast, low SES families tend to adopt strict, punitive, authoritarian parenting styles, leading to children's poor self-control and more likely to emulate risky health behaviors from their parents [15-17, 19, 21-25]. In other words, the intergenerational transmission of risky 
health behaviors is likely to be an "reverse gradient" with SES. However, some other researches showed that with the rise of SES, the intergenerational transmission effect of parental risky health behaviors to their children became more and more apparent $[26,27]$. Yu et al. (2010) proposed that higher education in rural China was often associated with more social activities where more cigarettes and wines were more accessible. Wu (2014)'s studies confirmed Yu's conclusion about the association between education and liquor drinking [28]. A Belgian study found that higher-educated mothers tended to have higher workloads and thus spent less time with their children, making their children more vulnerable to risky health behaviors [26].

Therefore, this study was intended to examine how parents affect children's risky health behaviors by taking advantage of the longitudinal database from the China Health and Nutrition Survey (CHNS), in the hope of adding up-to-date evidence to former cross-sectional studies. What's more, considering that adults often have a hard time making behavioral changes to rationally addictive behaviors, it may be more effective to prevent and reduce risky health behaviors in children from the perspective of reducing intergenerational transmission. Therefore, we further explored whether intergenerational transmission differed by parental SES in order to shed light to preventing children's health from the parent level.

\section{Methods}

\subsection{Data}

The primary database used in the present study was from the China Health and Nutrition Survey (CHNS). CHNS, an ongoing nationwide cohort project in China with ten available waves from 1989 to 2015 . These areas are representative and diverse in a wide range of socioeconomic factors (including income, education, and employment) and other related demographic, health, and nutritional factors. Because only the individuals aged between 20 and 45 were surveyed in 1989, we excluded the baseline data, only used data from 1991 to 2015 to make analysis, singled out smoking, alcohol drinking, and sugar-sweetened beverages (SSBs) drinking as proxies for risky health behaviors in children under 18 years old. We excluded samples with outliers and missing data, leaving 5946 observations in the smoking group, 7821observations in the alcohol drinking group, and 3537 observations in the SSBs drinking group.

\subsection{Measures}

The main dependent variables in this study were the surveyed children's smoking, alcohol drinking, and sugar-sweetened beverages (SSBs) drinking behaviors. Smoking was assessed based on the question "Have you ever smoked?", and was coded as 1 if the respondent answered "Yes". Alcohol drinking was assessed based on the question "Did you drink beer or any other alcoholic beverage?", and wascoded as 1 if the respondent answered "Yes." SSBs drinking was assessed based on the question "Did you drink soft drinks or sugared fruit?" and was coded as 1 for respondents whose answers were "Yes."

The key independent variables were the parental risky health behaviors of these children, which were also assessed based on the three questions above. To analyze how risky health behaviors transmit from parents to their children, we also included parental socioeconomic status variables, including educational attainment (completed years of formal education in regular schools), household per capita income (RMB in 2015 value) and career type (Manual labor/Non-manual labor). Demographic variable like age (years), gender (male/female) was also included. In addition, we controlled area (categorized as Western: Guangxi, Guizhou, and Chongqing; Northeastern: Liaoning and Heilongjiang; Central: Henan, Hubei, and Hunan; Eastern: Jiangsu, Shandong, Beijing, and Shanghai) and wave (1991, 1993, 1997, 2000, 2004, 2006, 2009, 2011 and 2015) effects.

\subsection{Statistical analysis}

Data analyses were conducted by using the STATA/SE 14.0. Descriptive statistics for both parental and children's risky health behaviors, including smoking, alcohol use, and drinking SSBs were reported as proportions, with corresponding Chi-square tests to examine whether there were statistically significant whether the risky health behaviors could be transmitted from parents to their children. Parental socioeconomic status and demographic variables were also estimated as proportions for categorical and means for variables continuous variables, with Chi-square tests for dichotomous variables and t-tests for continuous variables were conducted and reported their $p$-values. 
The result of We adopted a binary choice model for panel data with random effect specification after we conducted Hausman Test $\left(p_{\text {smoking }}=1.000, p_{\text {alcohol }}=0.9043, p_{\text {ssbs }}=0.7745\right)$ to investigate whether parental risky health behaviors could be transmitted and how these behaviors were transmitted. Odds ratios with their $p$-values were reported. The model was specified as:

$\ln \frac{P_{i, t}}{1-P_{i, t}}=\beta_{0}+\beta_{1}$ FatherBehavior $_{i, t}+\beta_{2}$ MotherBehavior $_{i, t}+\sum_{j=1}^{4} \beta_{3 j}$ FatherSES $_{i j, t}+$

$\sum_{j=1}^{4} \beta_{4 j}$ MotherSES $_{i j, t}+\beta_{5}$ Area $_{i, t}+\beta_{6}$ Wave $_{i, t}+\beta_{7}$ Gender $_{i, t}+\beta_{8}$ Age $_{i, t}+u_{i, t}$

The $\mathrm{P}_{\mathrm{i}, \mathrm{t}}$ here represented the probability of children's smoking, alcohol drinking, and sugar-sweetened beverages (SSBs) drinking behaviors; FatherBehavior ${ }_{i, t} /$ MotherBehavior $_{i}$ indicated whether the child 's father/mother had this kind of risky health behavior, including smoking, alcohol drinking, and SSBs drinking; FatherSES $\mathrm{S}_{\mathrm{ij}, \mathrm{t}} /$ MotherSES $_{\mathrm{ij}, \mathrm{t}}$ represented the child is father/mother's socioeconomic status; Wave $e_{i, t}$ indicated the time dummies to explore the dynamic evolution from 1993 to 2015 ; Area $_{i, t}$ indicated the region dummies to explore the region effects on children's risky health behaviors; Gender ${ }_{i, t}$ and Age $_{i, t}$ represented child 's gender and age individually. $\mathrm{u}_{\mathrm{i}, \mathrm{t}}$ represented the child individual effects. We used the model above to analyze the total sample, urban sample, and rural sample, respectively.

To understand the influence of different SES variables on intergenerational transmission of risky health behaviors, we grouped urban and rural parents according to their education level, income, and occupation type, respectively, used Model (1) without this variable for regression in different subgroups, and drew a bar chart with confidence interval. For parental education level, we divided them into subgroups with years of education less than or equal to 6 and those with years of education greater than 6. For income, those lower than or equal to the average are divided into the low-income subgroup, and those more than the average are the high-income subgroup. Finally, we divided the occupations into a blue-collar subgroup and a subgroup of other jobs, and then subgroup analysis was conducted. To test the difference in the coefficients FatherBehavior $r_{i, t}$ and MotherBehavior ${ }_{i}$ among different subgroups, a seemingly unrelated estimation test (SUEST) was used.

\section{Results}

\subsection{Descriptive analysis}

The variables we used in the present study are displayed in Table 2 for the entire sample and the Risky health behavior and Nonrisky health behavior samples.

The prevalence of smoking, alcohol drinking, and SSBs drinking in children were $4.37 \%, 6.43 \%$, and $82.16 \%$, respectively. Boys had significantly higher proportions of these three risky health behaviors than girls. Smoking and alcohol drinking children were significantly older than non-smoking and non-alcohol drinking children, while SSBs drinking children were significantly younger than non-SSBs drinking children.

Both fathers and mothers of smoking children had a significantly higher rate of smoking, while it's not significant in mothers. Both fathers and mothers of alcohol drinking children had a significantly higher rate of alcohol drinking than those of nonalcohol drinking children. Similarly, among children who drank SSBs, both their fathers and mothers had a significantly higher ratio of drinking SSBs than non-SSBs drinking children's fathers and mothers.

\subsection{Logistic regression results}

The results of logistic regression for intergenerational transmission of parental risky health behaviors in Chinese children are presented in Table 3. In the total sample, after controlling for confounding variables, children who had a smoking father were about $240.9 \%$ more likely to smoke $(p<0.001)$ than children whose father did not smoke. Similar intergenerational transmission of father's smoking behavior could be observed for rural children. The intergenerational transmission effect was even more pronounced among urban children: smoking father would increase the probability of children smoking by $2506 \%(p=0.034)$. 
Similarly, alcohol drinking fathers would increase the possibility of children alcohol drinking by $71.5 \%(p<0.001)$ in the total sample, $119.4 \%(p=0.001)$ in the urban sample, and $52.6 \%(p=0.012)$ in the rural sample, respectively. Alcohol drinking mothers would increase the possibility of children alcohol drinking by $257.4 \%(p<0.001)$ in the total sample, $214.7 \%(p<0.001)$ in the urban sample, and $239.5 \%(p<0.001)$ in the rural sample, respectively.

Likewise, in the total sample, children with an SSB drinking father were about $161.2 \%$ more likely to drink SSBs $(p<0.001)$ than children whose father did not drink SSBs. And SSBs drinking mother could increase the likelihood of children SSBs drinking by $259.2 \%$ ( $p<0.001)$. Similar intergenerational transmission of this behavior could be observed for both urban and rural children. Different gender would play an important role in the intergenerational transmission of risky health behaviors. Compared with girls, boys were about $8316 \%, 353.3 \%, 25.1 \%$ more likely to smoke, drink alcohol and drink SSBs, respectively. Age also played an important role in the intergenerational transmission of smoking and alcohol drinking. Similar effects could be observed for both urban and rural children.

Various parental socioeconomic status (SES) variables also significantly affected children's these behaviors. Higher parental per capita income would make both urban and rural children more likely to drink alcohol and SSB. However, the effects of educational attainment and occupation status were not consistent or even opposite between urban and rural areas and between parents.

\subsection{Subgroup analysis}

To further clarify the intergenerational transmission of urban and rural parental risky health behaviors between SES groups, the results of subgroup analysis and SUEST test can be found in Table 4 to Table 9, Figure 1 and Figure 2. Considering the unreliability of the subgroup analysis due to the small sample size on mothers' smoking, the maternal smoking transmission between different SES groups was not reported here.

\subsubsection{Subgroup analysis for urban families}

The higher the father's education level, the more significant the intergenerational transmission of smoking $\left(\mathrm{OR}_{\mathrm{LowEdu}}=16.89\right.$, $\left.\mathrm{OR}_{\text {HighEdu }}=29.52\right)$ and alcohol drinking $\left(\mathrm{OR}_{\text {LowEdu }}=1.997, \mathrm{OR}_{\text {HighEdu }}=2.314\right)$, but OR of SSBs drinking dropped from 5.302 to 2.393. From low education level to high education level, OR of mother's liquor drinking behavior went down from 3.545 to 3.509 and OR of maternal SSBs drinking reduced from 5.090 to 2.972, with insignificantly coefficients difference between low educational mother group and high educational mother group.

Comparing with non-manual labor fathers, blue-collar jobs fathers had more significant intergenerational transmission of smoking $\left(\mathrm{OR}_{\text {Blue-Collar }}=156.9, \mathrm{OR}_{\text {Others }}=29.67\right)$, alcohol drinking $\left(\mathrm{OR}_{\text {Blue-Collar }}=4.065, \mathrm{OR}_{\text {Others }}=1.644\right)$ and SSBs drinking $\left(\mathrm{OR}_{\text {Blue-Collar }}=5.164, \mathrm{OR}_{\text {Others }}=2.754\right)$. Non-manual labor mothers significantly showed less intergenerational transmission effects of liquor drinking $\left(\mathrm{OR}_{\text {Blue-Collar }}=3.660, \mathrm{OR}_{\text {Others }}=3.050\right)$ and $\mathrm{SSBs}$ drinking $\left(\mathrm{OR}_{\text {Blue-Colla } \mathrm{r}}=3.401, \mathrm{OR}\right.$ Others $\left.=3.361\right)$.

With the increase of income, father's intergenerational transmission effect of smoking and SSBs drinking was getting weaker and insignificant $\left(\mathrm{OR}_{\text {Lowlnc }}=174.2, \mathrm{OR}_{\text {Highlnc }}=3.007 ; \mathrm{OR}_{\text {Lowlnc }}=5.071, \mathrm{OR}_{\text {Highlnc }}=2.219\right)$. On the contrary, the transmission effect of fathers' wine drinking behavior became stronger $\left(O R_{\text {Lowlnc }}=2.061, O R_{H i g h l n c}=2.699\right)$ as income increased. Both mother's liquor drinking behavior $\left(\mathrm{OR}_{\text {Lowlnc }}=4.009, \mathrm{OR}_{\mathrm{Highlnc}}=1.874\right)$ and SSBs drinking behavior $\left(\mathrm{OR}_{\text {Lowlnc }}=2.966, \mathrm{OR}_{\mathrm{Highlnc}}=\right.$ 2.807) decreased from low-income group to high-income group.

\subsubsection{Subgroup analysis for rural families}

With the rise of paternal education level, intergenerational transmission of father's smoking $\left(\mathrm{OR}_{\mathrm{LowEdu}}=2.962, \mathrm{OR}_{\mathrm{HighEdu}}=\right.$ 4.038) and alcohol drinking $\left(\mathrm{OR}_{\text {LowEdu }}=1.333, \mathrm{OR}_{\text {HighEdu }}=1.743\right)$ increased, but OR of father's SSBs drinking behavior dropped from 3.294 to 2.339. Compared with low-education level mothers, OR of advance-educated mother's alcohol drinking behavior went up from 2.542 to 5.354 , and that of maternal SSBs drinking reduced from 5.408 to 3.403 , with significantly coefficients difference $\left(p_{\text {alcohol of SUEST }}=0.0888\right)\left(p_{\text {ssbs of SUEST }}=0.0203\right)$. 
Comparing with blue-collar jobs fathers, smoking of non-manual labored fathers would have a stronger effect on children's formation of this behavior $\left(\mathrm{OR}_{\mathrm{Blue}-\mathrm{Collar}}=2.995, \mathrm{OR}_{\text {Others }}=19.03\right)$ while non-manual labored fathers were less connected with children's alcohol drinking $\left(\mathrm{OR}_{\text {Blue-Collar }}=1.847, \mathrm{OR}_{\text {Others }}=1.171\right)$ and $\mathrm{SSBs}$ drinking $\left(\mathrm{OR}_{\text {Blue-Collar }}=2.842, \mathrm{OR}_{\text {Others }}=2.228\right)$. Meanwhile, non-manual labor mothers significantly showed less effects of liquor drinking $\left(\mathrm{OR}_{\mathrm{Blue}-\mathrm{Collar}}=3.289, \mathrm{OR}_{\mathrm{Others}}=\right.$ 5.290) and SSBs drinking $\left(\mathrm{OR}_{\text {Blue-Collar }}=4.045, \mathrm{OR}_{\text {Others }}=3.916\right)$.

With the increase of income, father's intergenerational transmission effect of smoking was getting stonger $\left(O R_{\text {Lowlnc }}=2.683\right.$, $\left.O R_{\text {Highlnc }}=29.74\right)$, and similarly, father's wine drinking behavior had similar effects $\left(O R_{\text {Lowlnc }}=1.577, \mathrm{OR}_{\text {Highlnc }}=1.762\right)$. Inversely, the influence of father's SSBs drinking behavior on their children's this behavior went through a process of weakening as income increased $\left(\mathrm{OR}_{\text {Lowlnc }}=3.310, \mathrm{OR}_{\text {Highlnc }}=1.225\right)$ and the coefficient difference was significant $\left(p_{\text {Ssbs of SUEST }}=0.0003\right)$.

Both mother's liquor drinking behavior $\left(\mathrm{OR}_{\text {Lowlnc }}=4.054, \mathrm{OR}_{\text {Highlnc }}=1.948\right)$ and SSBs drinking behavior $\left(\mathrm{OR}_{\mathrm{Lowlnc}}=4.591\right.$, $\left.\mathrm{OR}_{\text {Highlnc }}=3.035\right)$ decreased from low-income group to high-income group. ( $\left.p_{\text {ssbs of SUEST }}=0.0007\right)$ while the other was not.

\section{Discussion}

There were three central findings of the present study: 1) Risky health behaviors had significant intergenerational transmission effects. 2) The intergenerational transmission of mothers' alcohol consumption and SSBs drinking behavior was greater than that of fathers. 3) The influence of SES on intergenerational transmission in urban areas was different from that of rural children. For addictive behaviors like alcohol drinking and smoking, the intergenerational transmission mostly exhibited a downward SES gradient for urban families but a positive SES gradient for rural families. But the influence of parental SSB drinking behaviors shows a consistently downward SES gradient for both urban and rural families.

The present study showed that consistent with many previous findings [14-19, 21, 23-25], parental risky health behaviors could be significantly transmitted to their children. Children are usually easy to imitate their parents' behavior, even if it is negative and unhealthy $[14,29,30]$. So, parents' words and deeds are very important to prevent children's risky health behavior.

There were also differences between paternal influence and maternal influence. We found father's smoking behavior had a greater significant effect on leading children's smoking behavior than the mother's, contrary to many previous studies $[14,15$, $18,19]$. This may be because, compared with previous studies, the sample size of maternal smoking in this study was too small to make good statistical inferences. However, when it came to alcohol drinking and SSBs drinking, impacts of both mother's risky health behaviors were significantly higher than impacts of father's behaviors, samples, the impact of both mother's on children, which was consistent with some former researches [15, 24]. This may be because, compared with fathers, generally, mothers spent more time with their children. Therefore, the children could be more affected by mothers' behaviors rather than fathers' behaviors $[15,24]$.

The role of parental socioeconomic status (SES) in the intergenerational transmission of risky health behaviors for urban and rural children was not exactly the same. Generally speaking, there was a significant downward SES gradient in the intergenerational transmission of SSBs drinking behavior: the risky health behavior transmission effect of high-SES parents was weaker than that of low-SES parents. We also notified that the intergenerational transmission effect of urban mother's drinking behavior had downward gradients with all three SES variables, but rural mother's wine drinking behavior had a synthetic gradient with the rise of education level and occupational class. A similar situation occurred among fathers: rural father's risky health behaviors mainly appeared to show a synthetic gradient with SES, while urban father's smoking had downward gradients with the rise of occupational type and income.

This reflected SES had a dual influence on the intergenerational transmission of parental risky health behavior. On the one hand, higher SES means better family capital and better parenting style, which will prevent formations of children's unhealthy behaviors and reduce transmissions of these behaviors from their parents [24,31-34]. High-SES parents were usually well aware of the dangers of risky health behavior and were therefore inclined to discourage their children from these behaviors, while lowSES parents often did not care whether their children did or not, or even engaged in these behaviors in front of their children, setting a bad example for their children and leading them to engage in these behaviors [31, 34, 35]. There are some facts 
supporting the standpoint that higher SES can promote people's health and healthy behaviors. In the health model presented by Grossman, more affluent families tend to spend more money on health care like better-quality medical care and healthy food $[32,36]$. Well-educated parents would be more inclined to adopt healthy behaviors, both for themselves and their children, so the incidence of risky health behaviors among children will be lower [32, 33]. In addition to the fact that education could increase knowledge that promoting healthy behaviors, there were also potential indirect effects, such as smoother ways to get a job, better affordability of health-improving goods, less stress, better work environments where the high-SES were also exposed to healthier colleagues [37]. However, lower-SES people may care less about their health and that of their family members, be less responsive to health promotion and receive less information about how to get healthy and have limited access to health promotion services [31, 34]. Similar effects have been observed in risky health behaviors such as sugar-sweetened beverage drinking, which mainly exists in children and adolescents.

On the other hand, higher SES means that parents will devote more time to their own career to cope with higher workloads, more often ignored messages they received or enlisted the support of nannies or, in Chinese traditional culture, from their own retired parents, who were often less educated [26], leading to the absence of family education. Children with high-SES parents tended to have more disposable pocket money. All these may increase the risk of unhealthy behaviors of children. In the second case, the parents' deeds effect is bigger than their Words effect, which may promote intergenerational transmission of risky health behaviors in children. This may be because high-SES parents tended to have a higher status in their children's minds, children would be more likely to imitate parental risky health behaviors [14]. In our sample, for traditional rational addictive behaviors such as smoking and alcohol drinking, higher parental occupation and education level could enhance intergenerational transmission, which is an example of deeds effect bigger more than Words effect. These showed the necessity and importance of behavioral change starting from parents.

\section{Conclusions}

We observed that parents played an important part in the development of children's risky health behaviors. Parental risky health behaviors set a bad example for their children, for tempting and affecting children to imitate their parents' such behaviors. It is worth noting that, urban areas, especially urban mothers, mostly reflected the positive effects of SES while Fathers, especially those in rural areas, reflected adverse effects. It suggests that we should pay more attention to fathers' behaviors and parental awareness of health education in rural areas and invest in the rearing of their children. Apart from persuading children to drop these behaviors, we should pay more attention on reducing intergenerational transmission.

\section{Abbreviations}

CHNS: China Health and Nutrition Survey

SSB: Sugar-sweetened Beverage

SES: Socioeconomic Status

SUEST: Seemingly Unrelated Estimation Test

OR: Odds Ratio

\section{Declarations}

\section{Acknowledgements:}

This research uses data from China Health and Nutrition Survey (CHNS). We are grateful to research grant funding from the National Institute for Health $(\mathrm{NIH})$, the Eunice Kennedy Shriver National Institute of Child Health and Human Development (NICHD) for R01 HD30880, National Institute on Aging (NIA) for R01 AG065357, National Institute of Diabetes and Digestive and Kidney Diseases (NIDDK) for R01DK104371 and R01HL108427, the NIH Fogarty grant D43 TW009077 since 1989, and the

Page 7/15 
China-Japan Friendship Hospital, Ministry of Health for support for CHNS 2009, Chinese National Human Genome Center at Shanghai since 2009, and Beijing Municipal Center for Disease Prevention and Control since 2011. We thank the National Institute for Nutrition and Health, China Center for Disease Control and Prevention, Beijing Municipal Center for Disease Control and Prevention, and the Chinese National Human Genome Center at Shanghai.

Funding:

This work was supported by the Humanities and Social Science Foundation of Ministry of Education, China, No. 21YJC630060, National Natural Science Foundation of China [grant numbers 71673170, 71303137].

Availability of data and materials:

The datasets generated and analyzed during the current study are public available in the CHNS website [http://www.cpc.unc.edu/projects/china].

\section{Authors' contributions:}

ZY and JL conceptualized and designed the study. ZY analyzed the data. ZY and JL participated in explaining the data. ZY and $\mathrm{JL}$ participated in writing and revising the manuscript. All authors approved the final version of the paper. All authors have directly accessed and verified the underlying data reported in the manuscript.

\section{Declaration of Interest statement:}

The authors declare that they have no competing interests.

\section{Consent for publication:}

Not applicable

\section{Ethics approval and consent to participate:}

Data of this study was from the China Health and Nutrition Survey (CHNS). CHNS was approved by the Institutional Review Committees of the University of North Carolina at Chapel Hill and the National Institute of Nutrition and Food Safety, Chinese Center for Disease Control and Prevention.

\section{Reference}

1. Currie C, Roberts C, Settertobulte W, Morgan A, Smith R, Samdal O, Barnekow Rasmussen V, Organization WH: Young people's health in context: Health Behaviour in School-aged Children (HBSC) study: international report from the 2001/2002 survey. Copenhagen: WHO Regional Office for Europe; 2004.

2. Escobedo LG, Anda RF, Smith PF, Remington PL, Mast EE: Sociodemographic characteristics of cigarette smoking initiation in the United States: implications for smoking prevention policy. Jama 1990, 264:1550-1555.

3. Marmot MG, Kogevinas M, Elston MA: Social/economic status and disease. Annual review of public health 1987, 8:111-135.

4. Winkleby MA, Fortmann SP, Barrett DC: Social class disparities in risk factors for disease: eight-year prevalence patterns by level of education. Preventive medicine 1990, 19:1-12.

5. Catalano RF, Fagan AA, Gavin LE, Greenberg MT, Irwin Jr CE, Ross DA, Shek DT: Worldwide application of prevention science in adolescent health. The Lancet 2012, 379:1653-1664.

6. Chowdhury P, Balluz L, Town M, Chowdhury FM, Bartoli W, Garvin W, Akcin H, Greenlund KJ, Giles W: Surveillance of certain health behaviors and conditions among states and selected local areas-Behavioral Risk Factor Surveillance System, United 
States, 2007. Morbidity and Mortality Weekly Report: Surveillance Summaries 2010, 59:1-220.

7. Jefferis BJ, Power C, Graham H, Manor O: Effects of childhood socioeconomic circumstances on persistent smoking. American Journal of Public Health 2004, 94:279-285.

8. Underwood JM, Brener N, Thornton J, Harris WA, Bryan LN, Shanklin SL, Deputy N, Roberts AM, Queen B, Chyen D: Overview and methods for the youth risk behavior surveillance system-United States, 2019. MMWR supplements 2020, 69:1.

9. Hanson MD, Chen E: Socioeconomic status and health behaviors in adolescence: a review of the literature. Journal of behavioral medicine 2007, 30:263.

10. World Health Organization: WHO global report on trends in prevalence of tobacco use 2000-2025. World Health Organization; 2019.

11. World Health Organization: Global status report on alcohol and health 2018. World Health Organization; 2019.

12. Gui Z-H, Zhu Y-N, Cai L, Sun F-H, Ma Y-H, Jing J, Chen Y-J: Sugar-sweetened beverage consumption and risks of obesity and hypertension in chinese children and adolescents: a national cross-sectional analysis. Nutrients 2017, 9:1302.

13. Kit BK, Fakhouri TH, Park S, Nielsen SJ, Ogden CL: Trends in sugar-sweetened beverage consumption among youth and adults in the United States: 1999-2010. The American journal of clinical nutrition 2013, 98:180-188.

14. Pan J, Han W: Exploring the intergenerational persistence of health behaviour: an empirical study of smoking from China. BMC public health 2017, 17:1-9.

15. Brion M-J, Victora C, Matijasevich A, Horta B, Anselmi L, Steer C, Menezes AMB, Lawlor DA, Smith GD: Maternal smoking and child psychological problems: disentangling causal and noncausal effects. Pediatrics 2010, 126:e57-e65.

16. Flores G, Lin H: Factors predicting severe childhood obesity in kindergarteners. International journal of obesity 2013, 37:3139.

17. Göhlmann S, Schmidt CM, Tauchmann H: Smoking initiation in Germany: the role of intergenerational transmission. Health economics 2010, 19:227-242.

18. Melchior M, Chastang J-F, Mackinnon D, Galéra C, Fombonne E: The intergenerational transmission of tobacco smokingthe role of parents' long-term smoking trajectories. Drug and alcohol dependence 2010, 107:257-260.

19. Rainio SU, Rimpelä AH, Luukkaala TH, Rimpelä MK: Evolution of the association between parental and child smoking in Finland between 1977 and 2005. Preventive medicine 2008, 46:565-571.

20. Cockerham WC: Health lifestyle theory and the convergence of agency and structure. Journal of health and social behavior 2005, 46:51-67.

21. Almquist YB, Bishop L, Gustafsson N-K, Berg L: Intergenerational transmission of alcohol misuse: mediation and interaction by school performance in a Swedish birth cohort. J Epidemiol Community Health 2020, 74:598-604.

22. De Coen V, Vansteelandt S, Maes L, Huybrechts I, De Bourdeaudhuij I, Vereecken C: Parental socioeconomic status and soft drink consumption of the child. The mediating proportion of parenting practices. Appetite 2012, 59:76-80.

23. Mays D, Gilman SE, Rende R, Luta G, Tercyak KP, Niaura RS: Parental smoking exposure and adolescent smoking trajectories. Pediatrics 2014, 133:983-991.

24. Ren Y, Zhang Y, Campos BC, Loy J-P: Unhealthy consumption behaviors and their intergenerational persistence: The role of education. China Economic Review 2020, 62:101208. 
25. Wickrama KA, Conger RD, Wallace LE, Elder Jr GH: The intergenerational transmission of health-risk behaviors: Adolescent lifestyles and gender moderating effects. Journal of health and social behavior 1999:258-272.

26. Van den Branden S, Van den Broucke S, Leroy R, Declerck D, Hoppenbrouwers K: Oral health and oral health-related behaviour in preschool children: evidence for a social gradient. European Journal of pediatrics 2013, 172:231-237.

27. Yu X, Abler D: Interactions between cigarette and alcohol consumption in rural China. The European Journal of Health Economics 2010, 11:151-160.

28. Wu Y: China's consumer revolution 11. The Oxford companion to the economics of China 2014:85-89.

29. Loureiro ML, Sanz-de-Galdeano A, Vuri D: Smoking habits: like father, like son, like mother, like daughter? Oxford Bulletin of Economics and Statistics 2010, 72:717-743.

30. O'Loughlin J, Karp I, Koulis T, Paradis G, DiFranza J: Determinants of first puff and daily cigarette smoking in adolescents. American journal of epidemiology 2009, 170:585-597.

31. Cai L, Cui W, He J, Wu X: The economic burden of smoking and secondhand smoke exposure in rural South-West China. Journal of Asthma 2014, 51:515-521.

32. Currie J, Goodman J: Parental Socioeconomic Status, Child Health, and Human Capital. Int Encycl Educ 2010, 2.

33. Grossman M: Chapter 10 Education and Nonmarket Outcomes. In Handbook of the Economics of Education. Volume 1. Edited by Hanushek E, Welch F: Elsevier; 2006: 577-633

34. Yang T, Li F, Yang X, Wu Z, Feng X, Wang Y, Wang X, Abdullah ASM: Smoking patterns and sociodemographic factors associated with tobacco use among Chinese rural male residents: a descriptive analysis. BMC public health 2008, 8:1-7.

35. Wardle J, Jarvis M, Steggles N, Sutton S, Williamson S, Farrimond H, Cartwright M, Simon A: Socioeconomic disparities in cancer-risk behaviors in adolescence: baseline results from the Health and Behaviour in Teenagers Study (HABITS). Preventive medicine 2003, 36:721-730.

36. Grossman M: Chapter 7 - The Human Capital Model* *l am indebted to Robert Kaestner, Sara Markowitz, Tomas Philipson, andWalter Ried for helpful comments. In Handbook of Health Economics. Volume 1. Edited by Culyer AJ, Newhouse JP: Elsevier; 2000: 347-408

37. Cutler DM, Lleras-Muney A: Understanding differences in health behaviors by education. Journal of health economics 2010, 29:1-28.

\section{Tables}

Table 1 Descriptive Statistics 


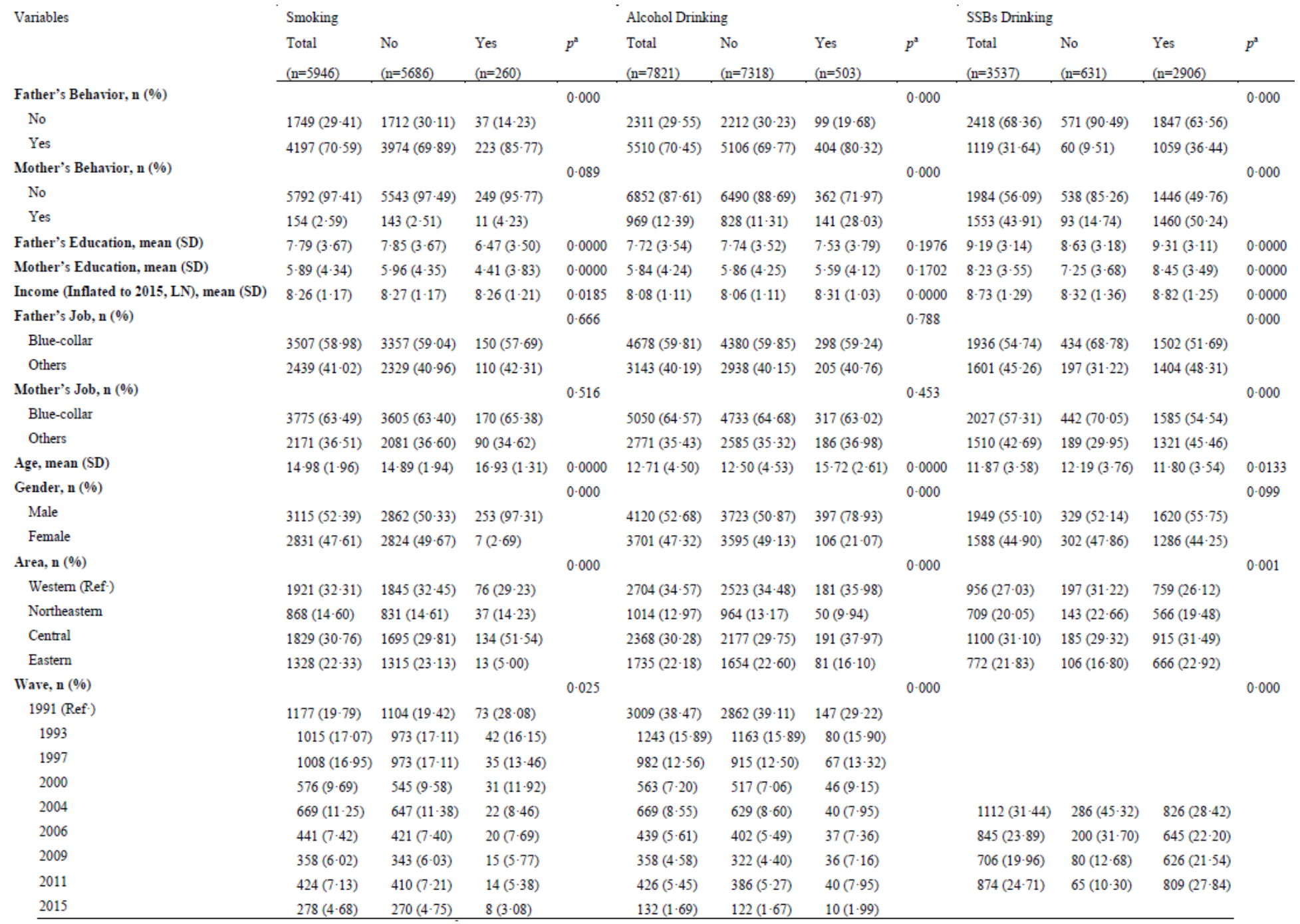

N.B. ${ }^{a}: X^{2}$ tests for dichotomous variables and t-tests for continuous variables.

Table 2 Results of random effect Logistic regression 


\begin{tabular}{|c|c|c|c|c|c|c|c|c|c|}
\hline \multirow[t]{2}{*}{ VARIABLES } & \multicolumn{2}{|l|}{ Smoking } & \multicolumn{3}{|c|}{ Alcohol Drinking } & \multirow[b]{2}{*}{ Rural } & \multicolumn{2}{|c|}{ SSBs Drinking } & \multirow[b]{2}{*}{ Rural } \\
\hline & All & Urban & Rural & All & Urban & & All & Urban & \\
\hline \multirow{2}{*}{$\begin{array}{l}\text { Father's } \\
\text { Behavior: } \\
\text { Yes }\end{array}$} & $3 \cdot 409 * * *$ & $26 \cdot 06^{\star \star}$ & $2 \cdot 835^{\star \star \star}$ & $1 \cdot 715^{\star \star \star}$ & $2 \cdot 194^{\star \star \star}$ & $1 \cdot 526^{\star \star}$ & $2 \cdot 573^{\star \star \star}$ & $2 \cdot 748$ *** & $2 \cdot 508$ *** \\
\hline & $(0 \cdot 882)$ & $(40 \cdot 05)$ & $(0 \cdot 737)$ & $(0 \cdot 234)$ & $(0.526)$ & $(0 \cdot 257)$ & $(0 \cdot 421)$ & $(0 \cdot 876)$ & $(0 \cdot 492)$ \\
\hline \multirow{2}{*}{$\begin{array}{l}\text { Mother's } \\
\text { Behavior: } \\
\text { Yes }\end{array}$} & $1 \cdot 784$ & $76 \cdot 22^{\star \star}$ & $1 \cdot 142$ & $3 \cdot 574^{\star \star \star}$ & $3 \cdot 147 * \star \star$ & $3 \cdot 395^{\star \star \star}$ & $3 \cdot 592^{\star * *}$ & $3 \cdot 394^{\star \star \star}$ & $3 \cdot 917^{\star \star \star *}$ \\
\hline & $(0.894)$ & $(164 \cdot 1)$ & $(0 \cdot 633)$ & $(0.530)$ & $(0.649)$ & $(0 \cdot 705)$ & $(0.504)$ & $(0.952)$ & $(0.656)$ \\
\hline \multirow{2}{*}{$\begin{array}{l}\text { Father's } \\
\text { Education }\end{array}$} & 0.961 & $1 \cdot 229$ & 0.954 & $1 \cdot 007$ & $1 \cdot 026$ & 0.999 & $1 \cdot 005$ & $0 \cdot 912^{\star}$ & $1 \cdot 030$ \\
\hline & $(0 \cdot 0314)$ & $(0 \cdot 251)$ & $(0 \cdot 0317)$ & $(0 \cdot 0197)$ & $(0.0338)$ & $(0.0257)$ & $(0.0201)$ & $(0 \cdot 0451)$ & $(0 \cdot 0244)$ \\
\hline \multirow{2}{*}{$\begin{array}{l}\text { Mother's } \\
\text { Education }\end{array}$} & 0.938 ** & $0 \cdot 706^{*}$ & 0.985 & 0.992 & 0.959 & $1 \cdot 001$ & $1 \cdot 037^{\star \star *}$ & $1 \cdot 105^{\star \star}$ & $1 \cdot 016$ \\
\hline & $(0 \cdot 0295)$ & $(0 \cdot 135)$ & $(0 \cdot 0328)$ & $(0 \cdot 0180)$ & $(0.0304)$ & $(0.0249)$ & $(0.0182)$ & $(0 \cdot 0495)$ & $(0 \cdot 0212)$ \\
\hline \multirow[t]{2}{*}{ Income } & 0.962 & $2 \cdot 281$ & 0.919 & $1 \cdot 160$ ** & $1 \cdot 235$ & $1 \cdot 071$ & $1 \cdot 165^{\star \star \star}$ & $1 \cdot 126$ & $1 \cdot 162^{\star \star \star}$ \\
\hline & $(0 \cdot 0846)$ & $(1 \cdot 278)$ & $(0 \cdot 0801)$ & $(0.0768)$ & $(0 \cdot 158)$ & $(0.0823)$ & $(0.0468)$ & $(0.0973)$ & $(0.0552)$ \\
\hline \multirow{2}{*}{$\begin{array}{l}\text { Father's Job: } \\
\text { Others }\end{array}$} & $1 \cdot 329$ & $9 \cdot 559$ & $1 \cdot 399$ & 0.913 & 0.998 & $1 \cdot 130$ & $1 \cdot 384^{\star \star}$ & $0 \cdot 811$ & $1 \cdot 556^{\star \star *}$ \\
\hline & $(0.338)$ & $(13 \cdot 53)$ & $(0 \cdot 374)$ & $(0 \cdot 136)$ & $(0.226)$ & $(0 \cdot 234)$ & $(0 \cdot 207)$ & $(0 \cdot 251)$ & $(0 \cdot 294)$ \\
\hline \multirow{2}{*}{$\begin{array}{l}\text { Mother's } \\
\text { Job: Others }\end{array}$} & 0.788 & $5 \cdot 384$ & $0.454^{\star \star}$ & 0.976 & 0.897 & 0.547 ** & $1 \cdot 244$ & $1 \cdot 210$ & $1 \cdot 008$ \\
\hline & $(0 \cdot 210)$ & $(8 \cdot 854)$ & $(0 \cdot 162)$ & $(0 \cdot 149)$ & $(0 \cdot 226)$ & $(0 \cdot 140)$ & $(0 \cdot 189)$ & $(0 \cdot 415)$ & $(0.204)$ \\
\hline \multirow[t]{2}{*}{ Age } & 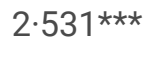 & $10 \cdot 13^{\star \star \star}$ & 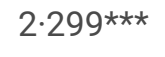 & $1 \cdot 429 * * \star$ & $1 \cdot 454^{\star \star \star}$ & $1 \cdot 408^{\star \star \star}$ & $1 \cdot 001$ & $1 \cdot 077^{\star \star \star}$ & 0.975 \\
\hline & $(0 \cdot 233)$ & $(4 \cdot 846)$ & $(0 \cdot 209)$ & $(0.0376)$ & $(0.0608)$ & $(0.0480)$ & $(0.0144)$ & $(0.0354)$ & $(0.0160)$ \\
\hline \multirow[t]{2}{*}{ Gender: Male } & $84 \cdot 16^{\star \star \star}$ & $135,565^{\star \star \star}$ & 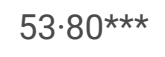 & $4 \cdot 533^{\star \star \star}$ & $3.982^{\star \star \star}$ & $5 \cdot 002^{\star \star \star}$ & $1 \cdot 251^{\star *}$ & $1 \cdot 193$ & $1 \cdot 268^{\star \star}$ \\
\hline & $(42 \cdot 32)$ & $(405,173)$ & $(27 \cdot 75)$ & $(0.635)$ & $(0 \cdot 817)$ & $(0.944)$ & $(0 \cdot 129)$ & $(0 \cdot 280)$ & $(0 \cdot 148)$ \\
\hline Area & Yes & Yes & Yes & Yes & Yes & Yes & Yes & Yes & Yes \\
\hline Wave & Yes & Yes & Yes & Yes & Yes & Yes & Yes & Yes & Yes \\
\hline \multirow[t]{2}{*}{ Constant } & $\begin{array}{l}1 \cdot 93 \mathrm{e}- \\
10^{\star \star \star}\end{array}$ & $0 * \star \star$ & $\begin{array}{l}3 \cdot 50 \mathrm{e}- \\
09 \star \star \star\end{array}$ & $\begin{array}{l}2 \cdot 52 \mathrm{e}- \\
05^{\star \star \star}\end{array}$ & $\begin{array}{l}1 \cdot 97 \mathrm{e}- \\
05^{\star \star \star}\end{array}$ & $\begin{array}{l}4 \cdot 69 \mathrm{e}- \\
05^{\star \star \star}\end{array}$ & $0 \cdot 287^{\star \star *}$ & 0.579 & $0.343^{\star *}$ \\
\hline & $\begin{array}{l}(4 \cdot 05 \mathrm{e}- \\
10)\end{array}$ & $(0)$ & $\begin{array}{l}\left(6 \cdot 96 \mathrm{e}^{-}\right. \\
09)\end{array}$ & $\begin{array}{l}(1 \cdot 85 \mathrm{e}- \\
05)\end{array}$ & $\begin{array}{l}\left(2 \cdot 81 \mathrm{e}^{-}\right. \\
05)\end{array}$ & $\begin{array}{l}\left(4 \cdot 37 e^{-}\right. \\
05)\end{array}$ & $(0 \cdot 115)$ & $(0.643)$ & $(0 \cdot 167)$ \\
\hline Observations & 5,946 & 1,682 & 4,264 & 7,821 & 2,124 & 5,697 & 3,537 & 1,063 & 2,474 \\
\hline
\end{tabular}

Table 3 Subgroup analysis of intergenerational transmission with different SES 
VARIABLES

Urban

Rural

OR (SD)

Suest Test

Observations OR (SD)

Suest Test

Observations

Smoking

Low Father

Education

$16.89(48.27) \quad X 2=0.04$,

$p=0.8468$

187

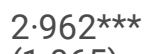

$X^{2}=0 \cdot 76$,

1858

High Father

$29 \cdot 52$ **

Education

(48.64)

1206

(1.065)

$p=0.3818$

$4.038^{\star \star \star \star ~}$

(2.033)

Low Mother

$0.232(0.795)$

$1 \cdot 202$

$(0 \cdot 641)$

2406

Education

$9,533^{* *}$

$(37,501)$

High Mother

$156 \cdot 9(512 \cdot 1) \quad X^{2}=1 \cdot 42$,

Father's Job: Blue-

collar $p=0.2340$

336

-

2724

912

825

Father's Job: Others $\quad 29 \cdot 67 *$

(58.76)

631

$(0 \cdot 874)$

$2.995^{\star *}$
$(0.874)$
$19.03^{\star \star}$

(25.52)

Mother's Job: Blue- $\quad 9,089$

collar

$(57,695)$

0.961

$(0 \cdot 532)$

2782

957

418

1482

Mother's Job: Others $7.763(15.59)$

585

-

$x^{2}=1 \cdot 95$

$p=0 \cdot 1625$

Low Income: Father's

Effect

$174 \cdot 2^{\star *}$

$(376 \cdot 2)$

$X^{2}=0 \cdot 27$,

$p=0.6013$

478

$2 \cdot 683^{\star \star \star}$

$(0.738)$

3229

High Income: Father's $\quad 3.007(2.479)$

Effect

Low Income:

0.00132

$(0.00538)$

$29 \cdot 74$

411

(64.33)

Mother's Effect

$8 \cdot 549$ **

High Income:

$(8 \cdot 145)$

478

$1 \cdot 501$

$(0 \cdot 807)$

1023

Mother's Effect

411

-

744

Alcohol Drinking

\begin{tabular}{|c|c|c|c|c|c|c|}
\hline $\begin{array}{l}\text { Low Father } \\
\text { Education }\end{array}$ & $\begin{array}{l}1.997^{\star} \\
(0.836)\end{array}$ & \multirow[t]{2}{*}{$\begin{array}{l}X^{2}=0.00 \\
p=0.9499\end{array}$} & 587 & $\begin{array}{l}1 \cdot 333 \\
(0 \cdot 346)\end{array}$ & \multirow[t]{2}{*}{$\begin{array}{l}x^{2}=0 \cdot 84 \\
p=0 \cdot 3584\end{array}$} & 2,420 \\
\hline $\begin{array}{l}\text { High Father } \\
\text { Education }\end{array}$ & $\begin{array}{l}2.314 \star \star \star \\
(0.699)\end{array}$ & & 1,537 & $\begin{array}{l}1.743^{\star \star} \\
(0 \cdot 389)\end{array}$ & & 3,277 \\
\hline $\begin{array}{l}\text { Low Mother } \\
\text { Education }\end{array}$ & $\begin{array}{l}3 \cdot 545^{\star \star \star} \\
(0 \cdot 966)\end{array}$ & \multirow[t]{2}{*}{$\begin{array}{l}X^{2}=0.99 \\
p=0.3189\end{array}$} & 829 & $\begin{array}{l}2 \cdot 542 \star \star \star \\
(0 \cdot 658)\end{array}$ & \multirow[t]{2}{*}{$\begin{array}{l}X^{2}=2 \cdot 90 \\
p=0.0888\end{array}$} & 3,565 \\
\hline $\begin{array}{l}\text { High Mother } \\
\text { Education }\end{array}$ & $\begin{array}{l}3.059 \star \star \star \\
(0.902)\end{array}$ & & 1,295 & $\begin{array}{l}5 \cdot 354 * \star \star \\
(1 \cdot 939)\end{array}$ & & 2,132 \\
\hline $\begin{array}{l}\text { Father's Job: Blue- } \\
\text { collar }\end{array}$ & $\begin{array}{l}4 \cdot 065^{\star \star \star} \\
(1 \cdot 896)\end{array}$ & \multirow[t]{2}{*}{$\begin{array}{l}X^{2}=4 \cdot 81 \\
p=0.0283\end{array}$} & 849 & $\begin{array}{l}1 \cdot 847 \star \star \star \\
(0 \cdot 410)\end{array}$ & \multirow[t]{2}{*}{$\begin{array}{l}x^{2}=1 \cdot 54 \\
p=0 \cdot 2142\end{array}$} & 3,792 \\
\hline Father's Job: Others & $\begin{array}{l}1 \cdot 644^{\star} \\
(0 \cdot 456)\end{array}$ & & 1,238 & $\begin{array}{l}1 \cdot 171 \\
(0 \cdot 328)\end{array}$ & & 1,905 \\
\hline $\begin{array}{l}\text { Mother's Job: Blue- } \\
\text { collar }\end{array}$ & $\begin{array}{l}3 \cdot 660 * \star \star \\
(1 \cdot 201)\end{array}$ & \multirow[t]{2}{*}{$\begin{array}{l}x^{2}=0 \cdot 45 \\
p=0.5016\end{array}$} & 651 & $\begin{array}{l}3 \cdot 289 * \star \star \\
(0 \cdot 820)\end{array}$ & \multirow[t]{2}{*}{$\begin{array}{l}X^{2}=0.69 \\
p=0.4048\end{array}$} & 4,399 \\
\hline Mother's Job: Others & $\begin{array}{l}3 \cdot 050 * \star * \\
(0 \cdot 780)\end{array}$ & & 1,473 & $\begin{array}{l}5 \cdot 290 \star \star \star \\
(1 \cdot 947)\end{array}$ & & 1,298 \\
\hline $\begin{array}{l}\text { Low Income: Father's } \\
\text { Effect }\end{array}$ & $\begin{array}{l}2 \cdot 061^{\star \star} \\
(0 \cdot 648)\end{array}$ & \multirow[t]{2}{*}{$\begin{array}{l}X 2=1 \cdot 25 \\
p=0 \cdot 2639\end{array}$} & 1348 & $\begin{array}{l}1 \cdot 577 \star \star \\
(0 \cdot 306)\end{array}$ & \multirow[t]{2}{*}{$\begin{array}{l}X^{2}=1 \cdot 00 \\
p=0 \cdot 3710\end{array}$} & 4707 \\
\hline High Income: Father's & $2 \cdot 699 \star \star$ & & 523 & $1 \cdot 762$ & & 792 \\
\hline
\end{tabular}

Page 13/15 


\begin{tabular}{|c|c|c|c|c|c|c|}
\hline Effect & $(1 \cdot 314)$ & & & $(0 \cdot 650)$ & & \\
\hline $\begin{array}{l}\text { Low Income: } \\
\text { Mother's Effect }\end{array}$ & $\begin{array}{l}4 \cdot 009 \star \star \star \\
(1 \cdot 135)\end{array}$ & \multirow[t]{2}{*}{$\begin{array}{l}X^{2}=0.51 \\
p=0 \cdot 4742\end{array}$} & 1348 & $\begin{array}{l}4 \cdot 054^{\star \star \star} \\
(0 \cdot 967)\end{array}$ & \multirow[t]{2}{*}{$\begin{array}{l}X^{2}=0.41 \\
p=0.5235\end{array}$} & 4707 \\
\hline $\begin{array}{l}\text { High Income: } \\
\text { Mother's Effect }\end{array}$ & $1 \cdot 874(0 \cdot 875)$ & & 523 & $\begin{array}{l}1.948 \\
(0.956)\end{array}$ & & 792 \\
\hline \multicolumn{7}{|l|}{ SSBs Drinking } \\
\hline $\begin{array}{l}\text { Low Father } \\
\text { Education }\end{array}$ & $5 \cdot 032(8 \cdot 027)$ & \multirow[t]{2}{*}{$\begin{array}{l}x^{2}=0.35 \\
p=0.5524\end{array}$} & 125 & $\begin{array}{l}3 \cdot 294 * \star \star \\
(1 \cdot 397)\end{array}$ & \multirow[t]{2}{*}{$\begin{array}{l}\mathrm{X}^{2}=1.91 \\
p=0.1669\end{array}$} & 604 \\
\hline $\begin{array}{l}\text { High Father } \\
\text { Education }\end{array}$ & $\begin{array}{l}2 \cdot 393^{\star \star \star} \\
(0 \cdot 789)\end{array}$ & & 924 & $\begin{array}{l}2 \cdot 339 * \star \star \\
(0.536)\end{array}$ & & 1,870 \\
\hline $\begin{array}{l}\text { Low Mother } \\
\text { Education }\end{array}$ & $\begin{array}{l}5 \cdot 090 \star \star \star \\
(3 \cdot 170)\end{array}$ & \multirow[t]{2}{*}{$\begin{array}{l}X^{2}=1 \cdot 45 \\
p=0 \cdot 2290\end{array}$} & 205 & $\begin{array}{l}5 \cdot 408^{\star \star \star} \\
(1 \cdot 650)\end{array}$ & \multirow[t]{2}{*}{$\begin{array}{l}X^{2}=5 \cdot 39 \\
p=0.0203\end{array}$} & 933 \\
\hline $\begin{array}{l}\text { High Mother } \\
\text { Education }\end{array}$ & $\begin{array}{l}2.972 * \star * \\
(0.943)\end{array}$ & & 835 & $\begin{array}{l}3 \cdot 403^{\star \star \star} \\
(0 \cdot 706)\end{array}$ & & 1,541 \\
\hline $\begin{array}{l}\text { Father's Job: Blue- } \\
\text { collar }\end{array}$ & $\begin{array}{l}5 \cdot 164^{\star} \\
(4 \cdot 799)\end{array}$ & \multirow[t]{2}{*}{$\begin{array}{l}X^{2}=0.46 \\
p=0.4966\end{array}$} & 429 & $\begin{array}{l}2 \cdot 842^{\star \star \star} \\
(0 \cdot 701)\end{array}$ & \multirow[t]{2}{*}{$\begin{array}{l}X^{2}=3.93 \\
p=0.0473\end{array}$} & 1,507 \\
\hline Father's Job: Others & $\begin{array}{l}2 \cdot 754 \star \star \star \\
(1 \cdot 067)\end{array}$ & & 634 & $\begin{array}{l}2 \cdot 228^{\star \star} \\
(0 \cdot 738)\end{array}$ & & 967 \\
\hline $\begin{array}{l}\text { Mother's Job: Blue- } \\
\text { collar }\end{array}$ & $\begin{array}{l}3 \cdot 401^{\star} \\
(2 \cdot 372)\end{array}$ & \multirow[t]{2}{*}{$\begin{array}{l}x^{2}=0.35 \\
p=0.5533\end{array}$} & 350 & $\begin{array}{l}4 \cdot 045^{\star \star \star} \\
(0 \cdot 798)\end{array}$ & \multirow[t]{2}{*}{$\begin{array}{l}X^{2}=3 \cdot 19 \\
p=0.0739\end{array}$} & 1,677 \\
\hline Mother's Job: Others & $\begin{array}{l}3 \cdot 361^{\star \star \star} \\
(1 \cdot 050)\end{array}$ & & 713 & $\begin{array}{l}3 \cdot 916 \star \star \star \\
(1 \cdot 236)\end{array}$ & & 797 \\
\hline $\begin{array}{l}\text { Low Income: Father's } \\
\text { Effect }\end{array}$ & $\begin{array}{l}5 \cdot 071 * \star * \\
(2 \cdot 621)\end{array}$ & \multirow[t]{2}{*}{$\begin{array}{l}X^{2}=4 \cdot 43 \\
p=0.0354\end{array}$} & 341 & $\begin{array}{l}3 \cdot 310 \star \star \star \\
(0 \cdot 868)\end{array}$ & \multirow[t]{2}{*}{$\begin{array}{l}X^{2}=13 \cdot 33 \\
p=0.0003\end{array}$} & 1312 \\
\hline $\begin{array}{l}\text { High Income: Father's } \\
\text { Effect }\end{array}$ & $2 \cdot 219(1 \cdot 286)$ & & 410 & $\begin{array}{l}1 \cdot 225 \\
(0 \cdot 407)\end{array}$ & & 885 \\
\hline $\begin{array}{l}\text { Low Income: } \\
\text { Mother's Effect }\end{array}$ & $\begin{array}{l}2 \cdot 966^{\star \star} \\
(1 \cdot 253)\end{array}$ & \multirow[t]{2}{*}{$\begin{array}{l}x^{2}=0.54 \\
p=0.4610\end{array}$} & 341 & $\begin{array}{l}4 \cdot 591 \star \star \star \\
(1 \cdot 043)\end{array}$ & \multirow[t]{2}{*}{$\begin{array}{l}x^{2}=11 \cdot 51 \\
p=0.0007\end{array}$} & 1312 \\
\hline $\begin{array}{l}\text { High Income: } \\
\text { Mother's Effect }\end{array}$ & $\begin{array}{l}2 \cdot 807^{\star} \\
(1 \cdot 498)\end{array}$ & & 410 & $\begin{array}{l}3.035^{\star \star \star} \\
(0.875)\end{array}$ & & 885 \\
\hline
\end{tabular}

seEform in parentheses, ${ }^{\star * \star} p<0 \cdot 01, \star \star * p<0 \cdot 05, * p<0 \cdot 1$

\section{Figures}

\section{Figure 1}

Subgroup analysis for urban families 

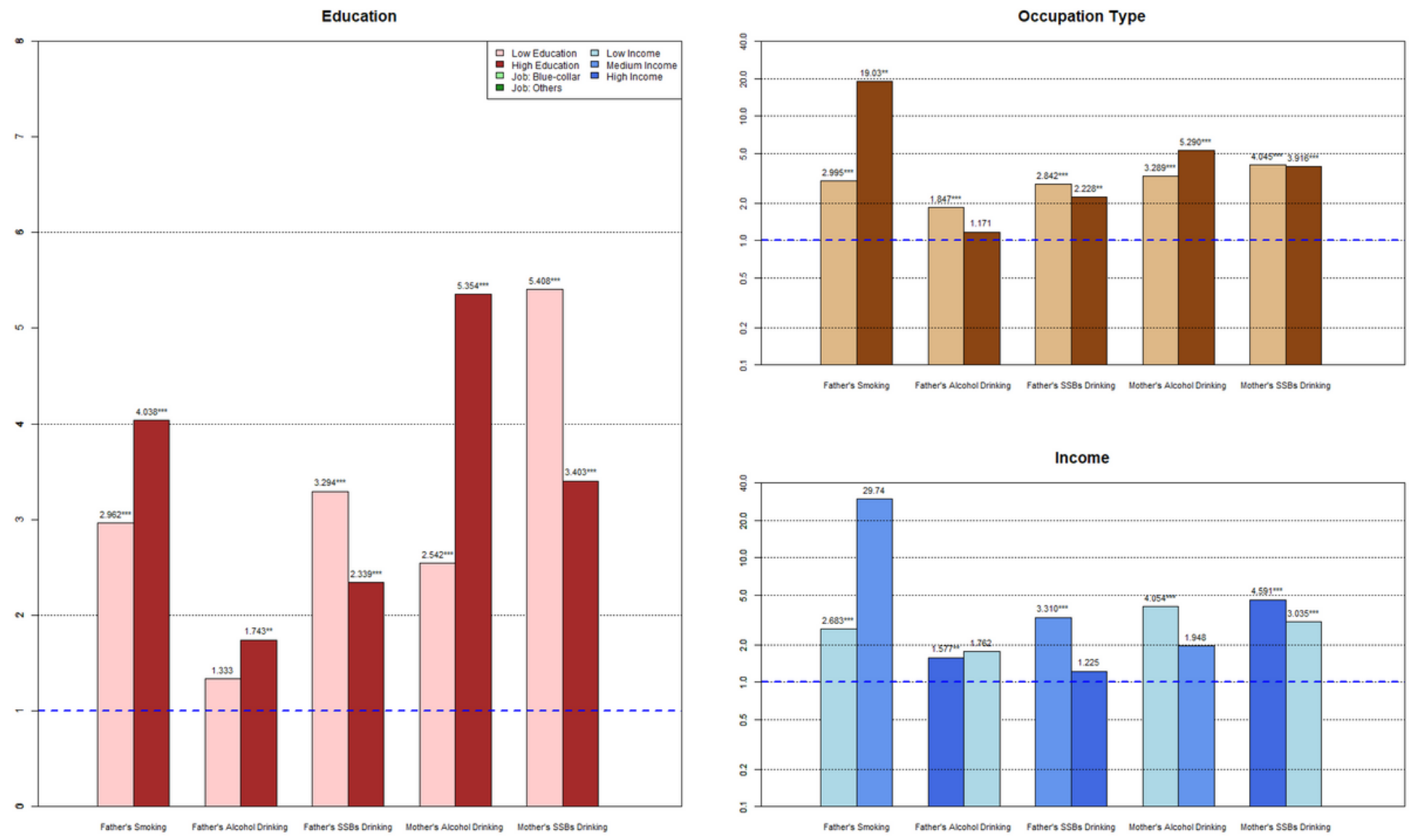

Figure 2

Subgroup analysis for rural families 